\title{
PENGAYAAN MATERI SIARAN AGAMA \\ UNTUK KERUKUNAN UMAT BERAGAMA PADA RADIO-RADIO SWASTA DI KALIMANTAN SELATAN
}

\author{
Surianor \\ UIN Antasari Banjarmasin
}

\begin{abstract}
Religion Islam is very rich with the material teachings about religious harmony, especially in relationships with adherents of other religions. But regrettably the propagation material about this harmony is still rarely delivered or socialized to the community, including through radio-radio that conducts the broadcast in the community. This paper discusses the teachings of Isam about religious harmony and loading of harmony material through the broadcast of preaching programs on radio stations in South Kalimantan.

Conclusion of this paper, the average radio in this area already has the broadcast of Islamic propagation, but the percentage of time is very little compared to other events, and from that little is still rarely filled with religious harmony material. The percentage of da'wah events only ranges from 3-10\% of the entire event material, and only Radio Gema Kuripan Amuntai whose da'wah material reaches $15 \%$.

In the future, religious teachings on harmony should be broadcasted also through educational and cultural events. Here not only the teachings of religion, but local cultural values that can be harmonized harmony can be broadcast. If the material is well processed, it will be interesting, and more importantly useful for people to improve harmony and avoid the rifts and conflicts nuanced SARA.
\end{abstract}

Keywords: religious broadcasting, Islamic preaching, harmony of religious people

\section{Pendahuluan}

Indonesia merupakan negara besar yang terdiri dari kepulauan yang berjumlah lebih dari 17.000 pulau, 5.000 pulau di antaranya sudah dihuni. Terdapat 5 pulau besar, 30 kepulauan kecil, dan selebihnya adalah pulau-pulau kecil. Dengan kondisi seperti itu Indonesia memiliki kemajemukan (heterogenitas) agama, suku, ras, latar belakang sejarah, sosial budaya, sumber daya alam, dan sebagainya. Semua itu merupakan warisan dan potensi bangsa yang penting untuk dilestarikan dan dikembangkan, serta dibingkai dalam suatu kesatuan, sehingga membawa manfaat bagi kehidupan masyarakat. ${ }^{5}$

Namun kemajemukan itu di sisi lain juga menyimpan potensi konflik yang berbahaya, jika tidak dikelola dengan baik. Ketika bangsa Indonesia masih hidup di alam penjajahan, penjajah suka menjadikan perbedaan itu sebagai senjata untuk memecah belah penduduk, melalui politik devide et impera, politik adu domba dan pecah belah kemudian dikuasai, sehingga perjuangan kita tidak solid dan bersatu. Tetapi kemudian bangsa kita sadar, mereka bersedia berjuang bergandeng tangan, dengan

${ }^{5}$ Imam AR, Obyek Wisata Nusantara, (Jakarta: Fery Agung, 2008), h. 2. 
menonjolkan persamaan dan mengcilkan perbedaan. Boleh dikata semua suku, pemeluk agama dan entitas budaya bergerak untuk melawan penjajah. Pada akhirnya kemerdekaan berhasil diraih dan terbentuklah NKRI yang berdiri di atas dasar Pancasila dan UUD 1945 dengan nuansa kehidupan Bhinneka Tunggal Ika.

Meskipun demikian, setelah bangsa ini merdeka, peersatuan dan kesatuan bangsa masih mengalami ancaman. Masih sering terjadi konflik dan perpecahan karena dipicu masalah politik, karena berbagai kelompok dan organisasi Islam juga berbedabeda pendapatnya tentang masalah politik, kepemimpinan, sosial, ekonomi, aliran keagamaan dan sebagainya. ${ }^{6}$

Menjelang dan di era awal reformasi tahun 1999-2001 sempat meletup berbagai peristiwa SARA di beberapa daerah di Indonesia, seperti di Ambon, Maluku, Poso, Sampit dan sebagainya yang banyak mengorban jiwa dan harta benda. Bahkan di Banjarmasin yang dianggap aman juga pernah meletus peristiwa serupa yang dikenal dengan Tragedi Jumat Kelabu tanggal 23 Mei 1997, yang banyak sekali memakan korban jiwa, harta benda, kebakaran fasilitas umum dan kerugian lainnya. ${ }^{7}$

Kerusuhan SARA di negeri ini, seperti terjadi di Ambon Maluku, sempat meluas hingga ke Poso, dan teramat banyak memakan korban. Menurut Amien Rais, sekiranya hal serupa terjadi di Jawa dan Sumatra, maka tamatlah riwayat Indonesia. ${ }^{8}$ Belakangan, kerusuhan SARA juga pernah tejadi di Papua, Aceh, Madura, Pontianak, Tarakan, Bekasi dan banyak lagi. Upaya merekatkan kembali kerukunan yang sempat terkoyak serta mencegah agar hal serupa tidak terjadi, sebagian pihak memandang perlu untuk merumuskan Undang-Undang Kerukunan Umat Beragama, disertai kajian dan solusi konkret melalui pendekatan lain.

Pertengahan Maret 2000 sejumlah pemuka agama dari Majelis Ulama Indonesia (MUI), Nahdlatul Ulama (NU), Muhammadiyah, Persekutuan Gereja-gereja Indonesia (PGI), Konferensi Wali Gereja Indonesia (KWI), Perwalian Umat Budha Indonesia (Walubi), dan sejumlah tokoh lintas agama bertemu guna merumuskan perlu tidaknya menyusun undang-undang yang mengatur kerukunan umat beragama di Indonesia. Pihak MUI menyatakan, UU itu diperlukan guna mengantisipasi kerusuhan bernuansa SARA. Sementara PGI menyatakan, UU itu tidak diperlukan karena akan mengundang permasalahan baru. Kalau mau dirumuskan, maka harus disosialisasikan lebih dahulu. PGI sebagaimana disuarakan oleh ketuanya saat itu Dr. Sularso Sopater. ${ }^{9}$

Dibukanya wacana kemungkinan penyusunan UU kerukunan umat beragama sebenarnya bukan soal baru. Jauh sebelumnya, Ketua Umum PB-NU di era 1980-an Gus Dur pernah melontarkan perlunya UU dimaksud, hal mana diamini pula oleh Nurcholish Madjid dan didukung oleh Menteri Agama saat itu Tarmizi Taher saat itu.

Memang kerukunan umat beragama merupakan hal yang sangat penting bagi bangsa Indonsia, dan bangsa ini sempat diberi predikat sebagai bangsa paling rukun di dunia dan banyak studi banding dunia guna mempelajari bagaimana cara kita merajut kerukunan. Namun dengan banyaknya kerusuhan bernuansa SARA, khususnya di masa-

${ }^{6}$ Ahmad Syafii Mufid,"Paham Islam Transnasional dan Demokratisasi di Indonesia, dalam Ahmad Syafii Mufid (Editor), Perkembangan Paham Keagamaan Transnasional di Indonesia, (Jakarta: Kementerian Agama RI, 2011), h. xviii.

${ }^{7}$ Departemen Agama RI, Konflik Sosial Bernuansa Agama, (Jakarta; Proyek Peningkatan

Pengkajian Kerukunan Hidup Umat Beragama, 2003), h.12.

${ }^{8}$ Amien Rais: “Ketimpangan Sosial Pemicu Konflik”, Gatra, 15 Juni 2002, h. 50.

9"Perlukah UU Kerukunan Umat Beragama?", Tempo, Edisi Januari 2001, h. 50-60. 
masa awal reformasi, predikat sebagai negeri yang rukun terasa tidak kurang lagi dan penuh tantangan.

Heterogenitas agama dan suku boleh dikata ada pada setiap bangsa di dunia, jadi bukan milik Indonesia saja. Karena itu banyak negara di dunia sudah memiliki UU tersebut, yang isinya mengatur kerukunan, melarang penghujatan dan penistaan agama serta berbagai tindakan yang dapat merugikan penganut agama lain baik fisik maupun psikis.

India sejak 1950 sudah memliki Konstitusi India, yang dari 395 pasal ada 4 pasal yang mengatur soal kebebasan beragama dan hubungan antarpenganut agama. India juga memiliki The Religious Endowment Act 1863 yang mengatur lalulintas sumbangan untuk tempat peribadatan. Juga The Religious Institution 1988 yang mencegah penyalahgunaan suatu lembaga keagamaan. Ada lagi Special Provisions Act 1998 yang mengatur larangan mengkonversi (mengubah) suatu tempat peribadatan, misalnya dari masjid menjadi kuil atau sebaliknya yang berdiri sejak 1947. Parlemen India mengeluarkan beberapa peraturan untuk masing-masing agama. Protection of Right on Divorce Act 1986 berisi peraturan perceraian untuk penganut Islam. The India Christian Marriage Act 1872 berisi peraturana perkawinan dan perceraian bagi penganut agama Kristen, Hindu dan Budha. Guna mengantisipasi penggunaan agama untuk kepentingan politik, dibuat peraturan yang melarang partai-partai politik menggunakan simbol-simbol agama.

Inggris punya UU serupa, namun yang dilindungi hanya Kristen Anglikan, karena Gereja Anglikan merupakan gereja resmi di Inggris dan ditetapkan dalam konstitusi, dengan pemimpinnya berada di pundak Ratu Inggris secara turun temurun. Lord Sumner, seorang kritikus, mempersoalkan masalah ini sebagai hal yang aneh, mengingat di Inggris ada sejumlah penganut agama Katholik, Protestan, juga Islam yang dalam beberapa dasawarsa terakhir berkembang pesat. Namun kritikan Sumner belum mampu mengubah keadaan. ${ }^{10}$

Inggris tidak menganggap hubungan antaragama sebagai suatu yang serius, bahkan penghujatan suatu agama dianggap hal biasa, hanya dianggap tindak pidana ringan dan sanksinya pun hanya denda yang ringan. Bahkan jika penistaan agama lain dilakukan secara lisan, tulisan, sopan dan ilmiah dan tidak bersifat permusuhan, semua itu dianggap tidak melanggar hukum. Itu sebabnya orang seperti Salman Rushdi yang menulis novel heboh The Satanic Verses dapat hidup tenang di Inggris, meskipun telah divonis mati secara in absentia oleh pengadilan Iran sejak era Khomeini.

Pakistan sudah punya dan cenderung keras dalam memberlakukan UU Kerukunan Umat Beragama. Sejak era Presiden Zia Ul Haq, UU ini mengancam hukuman mati kepada penghujat dan pelaku kerusuhan bertema agama. Tetapi perkembangan sesudah Zia Ul Haq tampak sulit memberlakukan peraturan ini. Baru dua orang yang pernah dijerat yaitu Selamat Masih dan Rahmat Masih yang menghujat Nabi Muhammad di sebuah masjid di Lahore, sehingga menyulut kerusuhan SARA. Teapi pengadilan tinggi kemudian mencabut vonis mati yang dijatuhkan oleh pengadilan negeri Lahore. Karena rakyat terus protes akhirnya keduanya lari dan minta suaka di Jerman. Tetangga Pakistan, Bangladesh telah pula punya UU serupa, tapi tak kunjung diberlakukan. Taslema Nasreen yang dituduh menodai agama di Dacca justru dilindungi oleh PM Begum Khaleda Zia, meski banyak rakyat menghendaki penulis wanita itu

10“Potret Kerukunan Beragama Mancanegara”, Tempo, Edisi Januari 2001, h. 55. 
dihukum mati. Belakangan Nasreen dibebaskan dengan uang jaminan USS 250, Agustus 1994. ${ }^{11}$

Bisa saja masalah kerukunan umat beragama dan pembinaannya didekati secara yuridis dengan menyiapkan peraturan perundang-undangan. Boleh juga dengan mendekatan struktural, misalnya melalui lembaga-lembaga lintas agama di Kementerian Agama (Bimas Kristen, Katolik, Hindu dan Budha), forum-forum organisasi Kerukunan Umat Beragama (KUB) dan sejenisnya. Tetapi tidak kalah pentingnya adalah pendekatan kultural, yaitu melalui dakwah Islam dan penyiaran agama melalui mediamedia yang diperkirakan dapat memupuk harmonisasi dan kerukunan umat beragama. Pendekatan ini sangat penting karena bersentuhan langsung dengan masyarakat.

\section{Pembahasan}

\section{Pengertian dan Ruang Lingkup Kerukunan Umat Beragama}

Kata rukun dalam bahasa Indonesia artinya sesuatu yang harus dipatuhi untuk sahnya suatu pekerjaan, asas, dasar, sendi, juga berarti baik dan damai, tidak bertengkar, tentang pertalian persahabatan, bersatu hati, besepakat. Kerukunan artinya perihal hidup rukun, rasa rukun, kesepakatan. ${ }^{12}$ Istilah rukun ini berasal dari bahasa Arab, ruknun, jamaknya arkan , artinya tiang sandaran. ${ }^{13}$ Dengan demikian, kerukunan beragama dapat diartikan kehidupan antarumat beragama yang rukun, damai, tertib, tenang, dan bersahabat satu dengan lainnya, tanpa terjadi pertengkaran dan percekcokan.

Istilah kerukunan umat beragama bukanlah istilah baru, khususnya di lingkungan Kementerian Agama. Menurut sejarahnya istilah ini telah muncul sejak diselenggarakannya Musyawarah Antar Agama yang diselenggarakan pada tanggal 30 November 1867 oleh pemerintah dan berlangsung di gedung Dewan Pertimbangan Agung Jakarta. Musyawarah ini diselenggarakan berangkat dari adanya persoalan yang menyangkut agama-agama di Indonesia, juga sebagai realisasi dari keanekaragaman suku, bahasa, adat istiadat dan agama yang sesungguhnya sudah menjadi kenyataan dan diterima sebagai kekayaan bangsa. ${ }^{14}$

Kementerian Agama RI telah Memiliki Pusat Kerukunan Umat Beragama (PKUB), yang di daerah-daerah dijabarkan dalam Forum Kerukunan Umat Beragama (FKUB) bersama instansi dan organisasi agama-agama yang ada di daerah. Keberadaannya dimaksudkan sebagai unit operasional kerukunan umat beragama dengan prinsip kebersamaan, kesetiakawanan dan saling menghormati dengan wawasan multikultural. Visinya adalah terciptanya kerukunan umat beragama dengan mengembangkan toleransi untuk mewujudkan perdamaian yang harmonis didasarkan atas kesadaran adanya perbeadan dalam rangka merekatkan kesatuan dan persatuan bangsa. Misinya adalah:

a. Mengupayakan pemantapan internalisasi pemahaman dan penghayatan ajaran agama;

b. Menciptakan adanya pendekatan humanis kultural dengan melepaskan pendekatan formal-struktural;

\footnotetext{
${ }^{11}$ Potret Kerukunan Beragama Mancanegara", Tempo, Edisi Januari 2001, h. h. 58.

${ }^{12}$ Depatemen Pendidikan dan Kebudayaan RI, Kamus Besar Bahasa Indonesia, (Jakarta: Balai Pustaka, 1990), h. 757-758.

${ }^{13}$ Mahmud Yunus, Kamus Arab-Indonesia, (Jakarta: Yayasan Penyelenggara Penterjemah dan Pentafsir Alquran, 1973), h. 147.

${ }^{14}$ Departemen Agama Kantor Wilayah Kementerian Agama Kalsel, Profil Kerukunan, (Banjarmasin:Sub Bagiam Humas dan KUB, 2006), h. 9.
} 
c. Memantapkan tri kerukunan umat beragama secara bertahap dan terjabarkan dalam kehidupan berbangsa, bernegara, bermasyarakat dan beragama.

d. Memantapkan daya tahan dan pemahaman umat beragama secara efektif dan membentuk forum kerukunan umat beragama di daerah. ${ }^{15}$

Untuk mewujudkan visi dan misi di atas maka Kementerian Agama mengajak instansi dan organisasi-organisasi terkait untuk bersama melaksanakan kebijakankebijakan berikut:

a. Memantapkan dasar-dasar kerukunan internal dan antarumat beragama serta antarumat beragama dengan pemerintah. Membangun harmoni sosial dan persatuan nasional dalam bentuk upaya mendorong dan mengarahkan seluruh umat beragama untuk hidup rukun dalam bingkai teologi yang ideal untuk menciptakan kebersamaan dan sikap toleransi.

b. Menciptakan suasana kehidupan beragama yang kondusif dalam rangka memantapkan pendalaman dan penghayatan agama serta pengamalan agama yang mendukung bagi pembinaan kerukunan intern dan antar umat beragama. Melakukan eksplorasi secara luas tentang pentingnya nilai-nilai kemanusiaan dan seluruh keyakinan plural umat manusia yang fungsinya dijadikan sebagai pedoman bersama dalam melaksanakan prinsip-prinsip berpolitik dan berinteraksi sosial satu sama lain dengan memperhatikan sikap keteladanan dan persuasif.

c. Melakukan pendalaman nilai-nilai spiritual yang implementatif bagi kemanusiaan yang mengarahkan kepada nilai-nilai ketuhanan, agar tidak terjadi penyimpanganpenyimpangan nilai sosial kemasyarakatan dan nilai-nilai keagamaan.

d. Memantapkan cinta kasih dan perdamaian dalam kehidupan beragama dengan cara menghilangkan rasasaling curiga terhadap pemeluk agama lain, sehingga tercipta suasana kerukunan yang manusiawi tanpa dipengaruhi oleh faktor-faktor tertentu.

e. Menyadari bahwa perbedaan adalah suatu realita dalam hidup bermasyarakat, karenanya hal itu dijadikan sebagai mozaik yang dapat memperindah fenomena kehidupan beragama. ${ }^{16}$

Sebagai tindak lajut kebijakan di atas, maka pemerintah dalam hal ini Kementerian agama bersama lembaga dan organisasi terkait dituntut untuk melaksanakan berbagai upaya dan program-program strategis, yaitu:

a. Pengendalian konflik, difokuskan pada daerah-daerah yang mengalami konflik melalui berbagai kegiatan rekonsiliasi dan rehabilitasi yang melibatkan berbagai elemen masyarakat.

b. Pencegahan konflik, difokuskan pada daerah-daerah yang dianggap memiliki potensi konflik melalui berbagai kegiatan pembinaan pada masyarakat dengan tematema dan upaya-upaya preventif yang mencegah untuk terjadinya konflik.

c. Pembinaan KUB, difokuskan pada daerah-daerah yang tersebar di 33 provinsi melalui berbagai kegiatan yang berorientasi pada pengertian akan makna kerukunan umat beragama dengan melibatkan berbagai lapisan masyarakat.

d. Pemantapan KUB, merupakan upaya kondusif yang mendorong terjadinya kerukunan hidup umat beragama secara mantap melalui berbagai kegiatan terstruktur yang diarahkan pada kesadaran bahwa perbedaan adalah suatu realitas dalam kehidupan bermasyarakat. ${ }^{17}$

${ }^{15}$ Ibid., h. 9.

${ }^{16}$ Ibid., h. 10.

${ }^{17}$ Ibid., h. 12-13. 
Tholhah Hasan menawarkan agar umat Islam melihat dan menekankan kepada sisi keadilan dan kemanusiaan ketika beruhubungan dengan penganut agama lain. Semua manusia berasal dari sumber yang satu, lalu berkembang menjadi berbagai macam suku bangsa, ras, budaya dan agama. Semua oada dasarnya sama, yang paling mulia adalah orang yang betaqwa. Pada waktu haji wada' Rasulullah menekankan etika global, bahwa Bangsa Arab tidak lebih tinggi dari bangsa-bangsa lainnya, kulit putih tidak lebih baik dari kulit hitam, kecuali kelebihan taqwanya saja. Semua orang harus berlaku adil kepada siapa saja, termasuk kepada orang yang berbeda agama. ${ }^{18}$

\section{Ajaran Agama tentang Kerukunan Umat Beragama}

Islam adalah agama dakwah yang bersifat universal, wajib disebarkan kepada segenap manusia, baik yang belum beragama Islam maupun sudah muslim. Banyak ayat Alquran terkait dengan hal ini, diantaranya QS al-Furqan ayat 1 yang artiny) Maha suci Allah yang telah menurunkan Al-Furqaan (Al Quran) kepada hamba-Nya, agar Dia menjadi pemberi peringatan kepada seluruh alam).

Di dalam surah Saba ayat 28 diterangkan pula yang artinya: (Dan Kami tidak mengutus kamu (Muhammad), melainkan kepada umat manusia seluruhnya sebagai pembawa berita gembira dan sebagai pemberi peringatan, tetapi kebanyakan manusia tiada mengetahui).

Oleh karena itu agama Islam harus disebarkan kepada seluruh manusia secara bijaksana (QS an-Nahl: 125). Apabila agama Islam sudah disampaikan, dan orang-orang tetap dengan keyakinan agamanya semula, maka Islam memberi toleransi, dalam arti tidak akan memaksakan agama kepada umat lain, dan tidak akan menghina agama dan sesembahan agama lain. Banyak ajaran Islam yang berisi prinsip kerukunan hidup dengan penganut agama-agama lain, di antaranya: QS al-Baqarah ayat 256 yang artinya: (Tidak ada paksaan untuk (memasuki) agama (Islam); Sesungguhnya telah jelas jalan yang benar daripada jalan yang sesat. karena itu Barangsiapa yang ingkar kepada Thaghut dan beriman kepada Allah, Maka Sesungguhnya ia telah berpegang kepada buhul tali yang Amat kuat yang tidak akan putus. dan Allah Maha Mendengar lagi Maha Mengetahui).

Senada dengan ayat ini, di dalam QS Yunus ayat 99 juga dinyatakan yang artinya: (Dan jikalau Tuhanmu menghendaki, tentulah beriman semua orang yang di muka bumi seluruhnya. Maka apakah kamu (hendak) memaksa manusia supaya mereka menjadi orang-orang yang beriman semuanya?)

Menurut Yusuf al-Qardhawi meskipun agama Islam merupakan agama terakhir dan untuk seluruh umat manusia, namun Islam tidak pernah memaksa siapa pun untuk memeluk agama Islam dan keluar dari agamanya, baik agama Yahudi, Nasrani maupun agama lainnya. Islam datang untuk memantapkan dan meningkatkan kebebasan, sampai kepada kebebasan beragama dan berakidah. Akan tetap penetapan ini mempunyai syarat-syarat tertentu, karena kebebasan tidak boleh dijadikan sebagai permainan. ${ }^{19}$

\footnotetext{
${ }^{18}$ Muhammad Tholhah Hasan, Islam Dalam Perspektif Sosio-Kultural, Jakarta: lantabora Press, 2005), h. 281-282.

${ }^{19}$ Yusuf Qardhawi, Fatawa Qardhawi, Alih bahasa Abdurrahman Ali Bauzir, (Jakarta: Risalah Gusti, 1994), h. 354.
} 
Jadi, walaupun dakwah Islam bersifat universal, namun pada saat yang sama agama Islam juga memiliki banyak ajaran kerukunan dan toleransi terhadap pemeluk agama lain, baik yang termaktub dalam Alquran, hadis maupun teladan Nabi Muhammad saw dan para sahabat. Ayat Alquran yang sangat terkenal berkaitan dengan toleransi beragama adalah QS al-Kafirun ayat 1-5 yang artinya: (Katakanlah: "Hai orang-orang kafir, aku tidak akan menyembah apa yang kamu sembah. dan kamu bukan penyembah Tuhan yang aku sembah. Dan aku tidak pernah menjadi penyembah apa yang kamu sembah, dan kamu tidak pernah (pula) menjadi penyembah Tuhan yang aku sembah. Untukmu agamamu, dan untukku agamaku).

Ada juga ayat lain yang melarang umat Islam menghina sesembahan agama lain, karena akan berakibat pemeluk agama lain juga akan menghina Allah dengan tanpa ilmu pengetahuan. Hal ini dinyatakan dalam QS al-An'am ayat 108 yang artinya: (Dan janganlah kamu memaki sembahan-sembahan yang mereka sembah selain Allah, karena mereka nanti akan memaki Allah dengan melampaui batas tanpa pengetahuan. Demikianlah Kami jadikan Setiap umat menganggap baik pekerjaan mereka, kemudian kepada Tuhan merekalah kembali mereka, lalu Dia memberitakan kepada mereka apa yang dahulu mereka kerjakan).

\section{Praktik Nabi Muhammad SAW tentang Kerukunan Beragama}

Ajaran kerukunan beragama dalam Islam tidak hanya tertulis, tetapi telah dipraktikkan dalam kehidupan Nabi Muhammad saw. Ketika Muhammad berusia 12 tahun, beliau diajak pamannya Abu Thalib untuk berdagang ke negeri Syam (Syria). Seorang pendeta Nasrani, Bahira, menyambut rombongan dagang dan sebagaimana kebiasaan orang-orang Arab senang menjamu tamu. Pendeta ini merasa bahwa kedatangan nabi akhir zaman sudah dekat dan akan segera muncul dari bangsa Arab, bukan dari kalangan Yahudi Israel. Dalam jamuan makan Bahira tidak melihat anak dimaksud, ia menanyakan berkali-kali kepada Abu Thalib apakah ada yang tidak ikut makan. Ketika diberi tahu bahwa ada anak kecil yang dipisahkan dari rombongan orangtua/dewasa, Bahira segera minta agar anak itu dihadirkan.

Setelah ditanya asal usul silsilah sang anak, dan kemudian Bahira melihat tanda kenabian (khatamun nubuwwah) di antara kedua bahu Muhammad, maka ia yakin anak itulah nabi akhir zaman yang ditunggu. Khawatir kalau-kalau keselamatan Muhammad terancam oleh kaum Yahudi yang tidak rela nabi akhir zaman lahir di luar golongan mereka, Bahira menasihati Abu Thalib dan paman Nabi ini pun meyakini kebenarannya. Maka ia segera membawa anak itu pulang ke Mekkah, seraya menjaganya baik-baik hingga dewasa, sebab dialah nabi akhir zaman. Abu Thalib pula yang membela dakwah Nabi dengan segenap jiwa raganya. Ini menunjukkan pendeta Nasrani tersebut merasa bertanggung jawab untuk menyelamatkan kedatangan agama Islam, dengan menjauhkan Nabi Muhammad kecil dari bahaya. ${ }^{20}$

Saat Nabi Muhammad pertama kali diangkat menjadi Rasul dan sedang dalam ketakutan karena baru saja ketemu Malaikat Jibril, beliau dibawa oleh istrinya Khadijah untuk menemui Warqah bin Naufal seorang tokoh tua kaum Nasrani di Mekkah. Di situ Warqah menasihati Muhammad agar tenang sebab beliaulah rasul terakhir. Sekiranya panjang umur Warqah berjanji akan membelanya dari bahaya. Sayang, beberapa bulan kemudian ia meninggal karena usia tua. Ini menunjukkan tokoh Nasrani Mekkah

\footnotetext{
${ }^{20}$ Muhammad Husain Haekal, Hayatu Muhammad, Alih bahasa Ali Audah, Sejarah Hidup Muhammad, (Jakarta: Litera Antarnusa, 1990), h. 56.
} 
tersebut punya andil agar Muhammad dan Khadijah terhindar dari keraguan dan ketakutan. ${ }^{21}$

Di masa-masa awal kerasulan Muhammad, terjadi perang besar antara Romawi (penganut Nasrani) versus Persia (beragama Majusi/penyembah api). Mulanya yaitu tahun 614-615 M. tentara Persia yang menang, sehingga kaum musyrik/kafir Quraisy bergembira karena merasa ada kesamaan dengan kepercayaan mereka. Kaum muslimin bersedih karena kaum beriman (Nasrani) berada di pihak yang kalah. Tetapi karena masih lemah, mereka belum bisa membantu secara fisik atau pasukan, hanya bisa berharap dan berdoa agar kaum Nasrani Romawi dimenangkan. Allah kemudian menurunkan QS. al-Ruum (Bangsa Romawi) berisi berita dan ramalan bahwa tentara Romawi akan dimenangkan dalam waktu dekat. Prediksi Alquran ini benar, karena ternyata tentara Romawi menang gilang gemilang, bahkan nyaris menduduki Madain, ibukota Persia (622 M). Peristiwa ini juga sebagai isyarat bahwa antara kaum muslimin dengan kaum Nasrani (ahl al-kitab) bersaudara, karena sama-sama beriman kepada Allah. ${ }^{22}$

Di saat umat Islam di Mekkah terjepit oleh tekanan kaum Quraisy, Nabi saw memerintah sejumlah pengikutnya hijrah ke Habsyi (Ethiopia) yang saat itu dipimpin Kaisar Negus Najasi yang beragama Nasrani. Negus menerima dengan baik orangorang Islam, bersedia melindungi dan memberi suaka bagi mereka, padahal dia masih Nasrani. Baru di akhir hayatnya Negus masuk Islam, dan Nabi saw mengajak kaum muslimin shalat gaib untuknya.

Dalam sejarah kehidupan Nabi Muhammad saw pun tercermin adanya kerukunan hidup beragama. Ketika akan hijrah ke Medinah, Nabi Saw meminta Abdullah al-Uraiqith, seorang musyrik sebagai guide. Hal ini karena Uraiqith seorang pemandu yang profresional dan tahu seluk beluk jalan ke Medinah meski tidak melalui jalur resmi guna menghindari kejaran kafir Quraisy. Sesampainya di Medinah Nabi menyuruh para sahabatnya mempelajari bahasa Ibrani agar mudah berkomunikasi dengan golongan Yahudi. ${ }^{23}$ Mengetahui orang-orang Yahudi berupuasa guna merayakan selamatnya Nabi Musa dan pengikutnya dari kejaran Fira'un, Nabi pun melakukan puasa sebagai penghormatan pada Musa, yang belakangan dikenal sebagai Hari Asyura. ${ }^{24}$

Kepada kaum Yahudi, Nabi saw mengenalkan QS Yusuf yang disebut ahsan alqosash (the best story/kisah terbaik) yang berisi lengkap tentang cerita Nabi Yusuf. Banyak Yahudi masuk Islam, sebab isinya sama bahkan lebih lengkap daripada kisah serupa yang mereka ketahui dari Taurat. Kepada sejumlah penganut agama dan sukusuku/kabilah di Madinah (Islam, Yahudi, Kristen dan Paganis), Nabi saw menjalin koalisi melalui Piagam Medinah. Di dalam diktum perjanjian, semua pihak harus saling bantu dan bertoleransi, menghormati eksistensi masing-masing, menjaga keamanan dan ketertiban, persatuan dan kesatuan, serta kompak mempertahankan Madinah dari serangan musuh dari dalam dan luar. ${ }^{25}$

\footnotetext{
${ }^{21}$ Ibid., h. 84.

${ }^{22}$ Lihat QS ar-Ruum ayat 1-4, lihat juga Imam Ibnu Katsir, Tafsir Ibnu Katsir, Jilid V, Alih bahasa Salim Bahreisy dan Said Bahreisy, (Surabaya: Bina Ilmu, 1999), h. 225-226.

${ }^{23}$ Lihat Imam al-Bukhari, Shahih al-Bukhari, Jilid IV, JUZ 8, (Beirut: Dar al-Fikr, 1401 H), h. 120.

${ }^{24}$ Haekal, Sejarah Hidup Muhammad, h. 192.

${ }^{25}$ Ibid., h. 200-201.
} 
Gubernur Romawi di Mesir, Muqauqius, ketika disurati Nabi agar menerima Islam, sangat menghormati Nabi, namun menolak dengan halus. Sang gubernur mengirimi Nabi beberapa hadiah, di antaranya dua orang budak wanita penganut Kristen Kopti, yaitu kakak beradik Maria dan Sirin. Maria diperistri oleh Nabi, dikenal dengan Mariah al-Qibtiyah. Selain Aisyah, Mariah sangat disayang Nabi, dan sempat melahirkan anak laki-laki bernama Ibrahim yang sangat dibanggakan Nabi karena mirip wajah beliau, sehingga menimbulkan kecemburuan istri-istri yang lain. Ibrahim meninggal di masa kanak-kanak, sehingga Nabi sangat bersedih.

Segolongan kaum Nasrani Najran pernah datang ke Medinah dan minta berdialog tentang masalah ketuhanan dan hukum. Nabi saw melayani dengan baik, dialog tidak dilaksanakan di rumah atau tempat lain, tetapi justru di Masjid Nabawi. Usai dialog, kaum Najran mengakui kebenaran jawaban Nabi, tetapi tidak bersedia meninggalkan agamanya. Mereka hanya minta hukum Islam diberlakukan di daerahnya. Nabi tetap gembira dan dengan lapang hati menyikapinya.

Salah seorang istri Nabi, Shafiyah binti Huyayy adalah putri Huyayy bin Akhtab, tokoh Yahudi Bani Nadhir yang sangat memusuhi Nabi. Meski sempat meracuni makanan Nabi dan para sahabat usai Perang Khaibar, karena sakit hati ayah dan keluarganya banyak terbunuh, namun setelah diperistri Nabi, ternyata Shafiyah adalah seorang istri yang salehah. Ketika kesulitan keuangan, Nabi saw menggadaikan baju besinya kepada seorang tetangganya yang Yahudi, dengan beberapa karung gandum. Gadai ini tidak kunjung tertebus sampai beliau meninggal dunia.

Beberapa kisah nyata di atas, menunjukkan kehidupan Nabi Muhammad Saw sangat berwarna-warni, tidak hitam putih dan monolitik, melainkan sangat pluralistik. Dalam kehidupan pribadi, keluarga dan sosial beliau terbuka dan menerima perbedaan suku, agama, rasa dan golongan. Beliau selalu menekankan, tidak ada kelebihan suku Arab atas suku lain, keutamaan warna kulit atas yang lain, kecuali ketaqwaannya saja. Dalam soal keyakinan agama, beliau gigih berdakwah, tetapi jika ditolak beliau tidak akan memaksa, sesuai prinsip Islam, la ikraha fiddin... (QS al-Baqarah: 256) Beliau tetap konsisten mengusung prinsip lakum dinukum waliyadin (bagimu agamamu dan bagi kami agama kami). Khalifah Umar bin Khattab pernah meminta agar budaknya yang bernama Asbaq dan beragama Nasrani agar masuk Islam, namun Asbaq menolak, maka Umar menyikapinya dengan membawa surah al-Baqarah di atas.

Beranjak dari beberapa ayat Alquran dan praktik kehidupan Nabi Muhammad saw, maka Majelis Ulama Indonesia (MUI) menggariskan beberapa hal, yaitu:

a. Umat Islam diperbolehkan untuk bekerja sama dan bergaul dengan umat agamaagama lain dalam masalah-masalah yang berhubungan dengan masalah keduniaan.

b. Umat Islam tidak boleh mencampuradukkan akidah dan peribadatan agamanya dengan akidah dan peribadatan agama lain.

c. Umat Islam mengakui kenabian dan kerasulan Isa al-Masih bin Maryam sebagaimana pengakuan kepada Nabi dan Rasul yang lain.

d. Mengikuti upacara keagamaan agama lain bagi umat Islam hukumnya haram. ${ }^{26}$

\section{Kearifan Lokal}

Setiap agama dan suku bangsa juga memiliki ajaran dan nilai-nilai luhur (adiluhung) serta kearifan lokal (local wisdom) yang dapat digunakan untuk menjalin

${ }^{26}$ Himpunan Fatwa Majelis Ulama Indonesia, (Jakarta: Departemen Agama dan MUI, 2003), h. 
persatuan, baik dengan etnis yang sama maupun berbeda. Berikut diberikan beberapa contoh kearifan lokal tersebut:

a. Pada masyarakat Kabupaten Konawe terdapat kearifan lokal seperti Kalosara dan Samaturu. Kalosara adalah jalinan yang utuh dari sehelai rotan yang berjalin tiga memutar ke kiri. Jalinan itu melambangkan sistem hukum dan perundang-undangan yang menyatukan dan mengikat ketiga komponen kekuatan dan kekuasaan, yaitu pemerintah, sistem kepercayaan (agama) dan adat istiadat. Samaturu mempunyai makna bersatu, bergotong royong, taat kepada aturan pemerintah, agama dan adat, serta saling menghormati satu sama lain.

b. Pada masyarakat Tolaki dikenal hidup berkelompok secara demokratis dalam satu lingkungan tertentu yang disebut tobu.

c. Pada masyarakat Kota Kendari, terdapat pepatah mepoko aso, yang artinya persatuan, mempersatukan dan medudulu, artinya bekerja sama dan bergotong antarsuku dan agama.

d. Pada masyarakat Muna terdapat filsafat hidup yang mendorong terciptanya kerukunan umat beragama, seperti dapo moa sighu, artinya saling berkasih sayang satu sama lain, dapo adha adhati artinya saling harga menghargai, dapo moo moologha artinya saling asih, asah, asuh, dapo piapiara, artinya tolong menolong, dapo angka angka ta simbao badha sebadha, artinya saling harga menghargai, saling kasih sayang, saling menopang dan menguatkan sebagaimana satu tubuh. ${ }^{27}$

e. Pada masyarakat Hindu Bali, terdapat ungkapan yang diambil dari masyarakat Hindu India yang berbunyi: Tiada kemiskinan bagi yang giat berusahal Tiada malapetaka bagi yang rajin berdoal Tiada pertengkaran bagi yang mengenalikan wicara/ Tiada bahaya bagi yang selalu waspada. ${ }^{28}$

f. Pada masyarakat Ambon-Maluku juga ada kearifan pela-gandong, sumpah darah agar masyarakat yang berbeda agama bersaudara dan tidak saling memusuhi. Di antara semboyan yang digunakan adalah "kitorang basudara" (kita orang bersaudara). ${ }^{29}$

g. Pada masyarakat Banjar juga kaya dengan peribahasa/ungkapan tradisional yang menganjurkan untuk hidup rukun dengan pihak/golongan lain, misalnya "asal mambawa bujur salamat" (asal bersifat jujur akan selamat), "banganga dahulu hanyar baucap" (berpikir dahulu baru berbicara), "kada tunggal banih basa gin ditakar" (tidak hanya padi, pembicaraan pun diukur), "baik-baik mambawa diri di banua urang" (hati-hati bergaul di kampung orang) dan sebagainya. ${ }^{30}$

Kearifan lokal itu pada umumnya sejalan saja dengan ajaran agama. Karenanya dapat digunakan untuk menjalin persatuan dan kesatuan, termasuk di dalamnya menjalin Kerukunan Umat Beragama.

\section{Siaran Agama melalui Radio untuk Kerukunan Umat Beragama}

\footnotetext{
${ }^{27}$ Ridwan Lubis (Editor), Menelusuri Kearifan Lokal di Bumi Nusantara, (Jakarta: Puslitbang Kehidupan Beragama Departemen Agama RI, 2005), h. 348.

${ }^{28}$ Ibid., h. 41.

${ }^{29}$ Sudjangi, "Konflik-konflik Sosial Bernuansa Agama (Studi Kasus Kerusuhan Ambon, dalam Departemen Agama RI, Konflik Sosial Bernuansa Agama, (Jakarta; Proyek Peningkatan Pengkajian Kerukunan Hidup Umat Beragama, 2003), h. 159.

${ }^{30}$ Lihat Ahmad Makkie dan Sjamsiar Seman, Peribahasa dan Ungkapan Tradisional Bahasa Banjar, (Banjarmasin: Dewan Kesenian Daerah Kalimantan Selatan, 1996).
} 
Materi ajaran agama tentang kerukunan umat beragama sebagaimana diuraikan di atas, tentu harus disampaikan kepada masyarakat melalui berbagai media, baik cetak maupun elektronik (audio dan audio-visual). Dalam tulisan ini penulis menekankan siaran tersebut melalui radio.

Radio mendapat julukan sebagai kekuasaan kelima, the fifth estate, setelah pers. Radio bersifat auditif, hanya dapat didengar. Dengan demikian radio merupakan media audio, yang disebut juga media dengar. Pendengar radio bisa santai, karena sambil mendengarkan radio seseorang dapat membaca koran atau aktivitas lainnya. Efektivitas radio terletak pada daya langsung, daya tembus, daya tarik, musik, kata-kata dan efek suara. ${ }^{31}$

Meskipun televisi lebih unggul dan sudah relative berusia tua, namun ia tidak pernah dijuluki sebagai kekuasaan keenam (the six estate). Hal ini karena radio dianggap lebih berpengaruh kuat. Ketika terjadi revolusi, pemberontakan, kudeta dan sejenisnya maka yang lebih dahulu dikuasai adalah radio. Menyerahnya Jepang dari Sekutu, dapat ditangkap oleh para pemuda Indonesia melalui radio, dan ketika Indonesia merdeka, maka rakyat banyak mendengarnya dari Radio Australia dan Radio Bandung. Ketika terjadi pemberontakan G 30 S PKI, mereka lebih dahulu meguasai RRI dan menyiarkan gerakannya di sana, dan RRI ini pulalah yang kemudian lebih dahulu dikuasai oleh TNI pimpinan Soeharto ketika menumpas G 30 S PKI. Keunggulan radio, ia tidak mengenal jarak, ruang dan rintangan. Berapa pun jauhnya jarak, semuanya dapat dijangkau oleh siaran radio. Gunung, lembah, daratan dan lautan tidak menjadi masalah bagi radio. Batas negara dan benua menjadi sirna. ${ }^{32}$

Menurut Wawan Kuswandi, sebagai media radio mampu memberikan nilai yang sangat spektakuler dalam misi-misi pergauklan hidup manusia saat ini. Kekuatan dari media radio adalah mampu menguasai jarak dan ruang, karena teknologi radio menggunakan gelombang elektromagnetik, kabel dan tibel yang dipancarkan melalui satelit. Kemampuannya menjangkau massa dengan sendirinya sangat besar. Adanya suara menyebabkan radio lebih menarik, mudah diterima dan memberi pengaruh pada pendengar. ${ }^{33}$

Di seluruh wilayah NKRI radio-radio masih bertebaran, baik milik pemerintah (RRI) maupun milik swasta dan organisasi (radio komunitas). Memang ada kecenderungan radio-radio mulai ditinggalkan oleh sebagian kalangan orang, namun bagi sebagian lainnya siaran radio masih diikuti dan dijadikan sebagai sumber informasi yang utama.

\section{Acara-acara Dakwah Radio di Kalsel}

Di Kalimantan Selatan, selain RRI terdapat sejumlah radio siaran swasta niaga yang sedikit banyak juga menyiarkan acara-acara keagamaan (dakwah Islam). Kemudian ada juga acara pendidikan dan kebudayaan. Melalui kedua jenis acara ini

\footnotetext{
${ }^{31}$ Aep Kusnawan, "Tabligh Melalui Radio”, dalam Aep Kusnawan, et al., (1995), Komunikasi Penyiaran Islam, (Bandung: Fakultas Dakwah IAIN Sunan Gunung Jati, 1995), h. 1.

${ }^{32}$ Onong Uchjana Effendie, Ilmu, Teori dan Filsafat Komunikasi, (Bandung: Citra Aditya Bhakti, 1993), h. 142.

${ }^{33}$ Wawan Kuswandi, Komunikasi Massa: Sebuah Analisis Media Radio, (Jakarta: Rineka Cipta, 1996), h. 23.
} 
dapat diselipkan materi-materi tentang kerukunan umat beragama. Persentasi acara tersebut dapat dilihat pada tabel berikut:

Tabel 1. Persentasi Acara Dakwah, Pendidikan dan Kebudayaaan pada Radio-radio Swasta di Kalsel

\begin{tabular}{|l|l|l|l|}
\hline No. & \multicolumn{1}{|c|}{ Nama Radio /Alamat } & \multicolumn{1}{|c|}{$\begin{array}{c}\text { Dakwah } \\
\text { Islam }\end{array}$} & $\begin{array}{c}\text { Pendidikan \& } \\
\text { Kebudayaan }\end{array}$ \\
\hline 1 & Gema Kuripan Amuntai & $15 \%$ & $5 \%$ \\
\hline 2 & Tanjugpuri Perkasa Tanjung & $5 \%$ & $10 \%$ \\
\hline 3 & Dhirgahayu Barabai & $10 \%$ & $10 \%$ \\
\hline 4 & Swara Barabai & $5 \%$ & $10 \%$ \\
\hline 5 & Gema Amandit Kandangan & $10 \%$ & $5 \%$ \\
\hline 6 & Purnama Nada Kandangan & $5 \%$ & $5 \%$ \\
\hline 7 & Swara Tapin Raya Rantau & $5 \%$ & $10 \%$ \\
\hline 8 & Swara Ruhui Rahayu Rantau & $10 \%$ & $10 \%$ \\
\hline 9 & Gema Meratus Batulicin & $10 \%$ & $5 \%$ \\
\hline 10 & Gematara Batakan & $5 \%$ & $10 \%$ \\
\hline 11 & Telerama Banjarmasin & $5 \%$ & $5 \%$ \\
\hline 12 & $\begin{array}{l}\text { Kharismanada Rasisonia } \\
\text { Banjarmasin }\end{array}$ & $5 \%$ & $10 \%$ \\
\hline 13 & $\begin{array}{l}\text { Sindotrijaya Banjarmasin } \\
\text { Chandra Rasisonia }\end{array}$ & $\begin{array}{l}10 \% \\
(\text { Kristen })\end{array}$ & $10 \%$ \\
\hline 14 & $\begin{array}{l}\text { Chandara } \\
\text { Banjarmasin }\end{array}$ & $10 \%$ \\
\hline 15 & $\begin{array}{l}\text { Citraswara Pelangi Indah } \\
\text { Banjarmasin }\end{array}$ & $5 \%$ & $10 \%$ \\
\hline 16 & Citra Posindo Banjarmasin & $3 \%$ & $5 \%$ \\
\hline
\end{tabular}

Selama ini materi dakwah yang bermuatan kerukunan umat beragama masih kurang. Hal ini karena materi dakwah tersebut disiarkan dalam banyak variasi mata acara. Sebagaimana dapat dilihat dari program siaran keagamaan pada Radio Gema Kuripan, menurut hasil penelitian yang dilakukan oleh Dewita Shanty (2011), mata acara dakwah tersebut mencakup siraman rohani, pengajian Alquran, dialog interaktif keagamaan, kaifa, azan Maghrib, mimbar agama Islam, shalat Jumat, tafsir Alquran, kuliah Subuh, lagu-lagu nasyid, dzikir dan tahlil.

Relatif banyaknya acara dakwah di radio Gema Kuripan Amuntai (15\%) ini tidak terlepas dari kondisi sosial masyarakat pendengar yang mayoritas bahkan hampir $100 \%$ muslim. Agama yang menurut Kotler bagian dari kebudayaan, memang termasuk salah satu faktor yang mempengaruhi kepuasan seseorang atau sekelompok orang. Artinya bagi orang Islam yang taat beragama, siaran radio yang bermuatan dakwah lebih disenangi dan memberi kepuasan dari siaran yang tidak bermuatan dakwah. Hal ini sesuai pula dengan penelitian Shanti, yaitu $70 \%$ pendengarnya menyenangi acaraacara dakwah dan $30 \%$ merasa biasa-biasa saja. Adapun metode dakwah yang lebih disenangi pendengar, $60 \%$ menyenangi ceramah agama, $22 \%$ dialog interaktif dan $18 \%$ menyenangi tanya jawab melalui SMS.

Namun pada radio-radio lainnya selain Gema Kuripan, acara dakwah relatif sedikit, itu pun masih terbagi dalam beberapa mata acara, sebagai berikut: 
Radio Tanjungpuri Perkasa Tanjung, Siaran acara agama berupa Manajemen Qalbu, Nada dan Dakwah, Ceramah Agama, Adzan Maghrib dan Nasyid. Radio Dirgahayu acara agama disajikan dalam bentuk Hikmah Fajar, pengajian Alquran, adzan Maghrib dan qasidah. Acara Hikmah Fajar diisi dengan pemutaran lagu-lagu islami dan siaran rekaman ceramah ulama lokal, khususnya KH Muhammad Bakhiet, sebagaimana juga disiarkan oleh Banjar TV yang masih satu manajemen dengan Radio Dirgahayu Banjarmasin.

Radio Swara atau Radio Nirwana FM Barabai, acara agama disajikan dalam bentuk Mutiara Fajar di setiap pagi pukul 06.00-07.00 yang diisi dengan ceramah agama, dan Mutiara Senja di setiap petang pukul 18.00-19.00 yang diisi dengan pengajian Alquran, adzan Maghrib dan iqamah.

Radio Gema Amandit acara dakwah diformat dalam bentuk Nuansa Islami dan azan Zuhur, pengajian Alquran dan azan Maghrib, rekaman ceramah pengajian Darul Muhibbin asuhan KH Muhammad Bakhiet dan Hikmah/Tafsir Alquran.

Radio Purnama Nada Kandangan acara dakwah disajikan dalam bentuk Mutiara Hikmah dan pengajian Alquran, adzan Maghrib dan qasidah. Mutiara Hikmah diisi dengan pemutaran lagu-lagu religi dan rekaman ceramah ustadz lokal.

Radio Swara Tapin Raya, acara agama dikemas dalam bentuk Sentuhan Fajar berupa ceramah agama, voice of Islam, pengajian Alquran dan adzan Maghrib, dan Majalah Udara bekerja sama dengan Media Islam.net.

Radio Swasra Ruhui Rahayu Rantau acara dakwah disajikan dalam bentuk Mutiara Kehidupan, Bamajlis dan Batarbang serta pengajian Alquran, adzan Maghrib dan qasidah. Mutiara Kehidupan diisi dengan pemutaran lagu-lagu religi dan rekaman ceramah ustadz lokal. Bamajlis diisi dengan pemutaran hasil rekaman dari majelismajelis taklim di seputar Kabupaten Tapin, dan Batarbang adalah pemutaran hasil rekaman dari kelompok Maulid al-Habsyi yang ada di masyarakat.

Radio Gema Meratus Batulicin acara dakwah disajikan dalam bentuk acara Manajemen Qalbu, yang berisi ceramah agama Islam dan Nirwana Batulicin Bersujud yang berisi gelaran lagu-lagu bernafaskan Islam sambil menanti adzan dan shalat Maghrib.

Radio Gematara Batakan acara dakwah dikemas dalam bentuk Penyejuk Rohani dan Siaraman Qalbu. Penyejuk Rohani disampaikan dalam bentuk pemutaran ceramah agama oleh KH Muhammad Bakhiet Barabai, dilanjutkan dengan sapaan kepada pendengar agar bersemangat dalam memulai aktivitasnya. Siraman Qalbu juga dilakukan dalam bentuk pemberian ceramah agama didahului dengan lagu-lagu bernuansa islami. Radio Telerama Banjaramasin, radio ini tidak menjelaskan bentuk acara agama yang $5 \%$ tersebut.

Radio Kharismanada Rasisonia, siaran agama pada radio ini adalah untuk agama Kristen dalam acara yang disebut dengan Salam Kasih, Nada Kasih dan Senandung Kasih. Isi acara Salam Kasih adalah pemutaran lagu-lagu gereja dan rekaman khutbah pendeta di Kota Banjarmasin. Nada Kasih dan Senandung Kasih berisikan pemutaran lagu-lagu gereja. Pada radio ini tidak disiarkan dakwah agama Islam. Begitu juga dengan Radio Sindotrijaya Banjarmasin, acara agama dikemas dalam acara embun pagi, berisi talk show ringan berisi motivasi ajaran agama (Kristen) untuk memulai hari yang dihubungkan dengan berbagai masalah dan realitas kehidupan sehari-hari.

Radio Chandra Rasisonia Banjarmasin, acara dakwah Islam disajikan dalam bentuk kuliah Subuh berupa ceramah agama pada pukul 05.00-06.00, dan lagu-lagu islami pada pukul 18.00-19.30. Radio Citraswara Pelangi Indah Banjarmasin, acara 
dakwah dikemas dalam acara Pelangi Hati dan Senandung Pelangi. Pelangi hati pada pukul 06.00-07.00 diisi dengan pemutaran lagu-lagu bernuansa islami serta rekaman ceramah ustadz lokal. Sedangkan Senandung Pelangi diisi dengan pemutaran lagu-lagu islami dan dangdut islami sebelum dan sesudah adzan Maghrib. Radio Citra Posindo, radio ini hanya menyiarkan materi agama sebesar $3 \%$ dan siaran agama tersebut tidak disebutkan secara jelas jenis acaranya.

Berdasarkan pengamatan penulis, pada radio-radio di atas, selama ini masih jarang menampilkan materi dakwah yang berisi ajaran-ajaran tentang kerukunan umat beragama. Yang ada hanya dakwah menurut agama masing-masing, yaitu dakwah Islam bagi orang Islam dan siaran agama Kristen bagi orang Kristen. Tidak ditemui muatan dakwah yang bersifat lintas agama untuk menjalin kerukunan. Padahal materi yang bermuatan kerukunan beragama ini dapat dimuat dalam siaran radio, khususnya dalam bentuk ceramah agama, mimbar agama Islam, kuliah Subuh, tafsir Alquran, dialog interaktif dan sebagainya.

Kurangnya materi dakwah yang bermuatan kerukunan beragama ini kemungkinan disebabkan di daerah ini tidak ada ulama atau juru dakwah yang ahli tentang materi kerukunan agama-agama, ilmu perbandingan agama dan sejenisnya. Keahlian mereka hanya pada agama yang dianutnya saja. Dari pihak perusahaan radio dan redaksi penyiaran juga mungkin masih kurang komitmen untuk menyiarkan acaraacara dakwah, termasuk dengan tema kerukunan, hal ini besar kemungkinan karena pertimbangan ekonomi, efisiensi, iklan, dll. Kemungkinan lain karena kebanyakan penduduk di daerah Kalimantan Selatan, mayoritas beragama Islam, sehingga materi siaran dakwah radio yang bermuatan kerukunan umat beragama belum dianggap perlu dan mendesak.

Sebenarnya seiring dengan pertambahan dan mobilitas penduduk, akulturasi budaya dan sebagainya, boleh dikatakan di setiap daerah sudah dihuni oleh penduduk yang berbeda-beda agama. Artinya, selain muslim, penganut agama lain seperti Kristen, Katolik, Hindu, Budha dan Konghucu juga besar. Bahkan salah satu kabupaten di Kalimantan Selatan yaitu Kabupaten Balangan, ada satu desa yang bernama Kapul Kecamatan Halong, di mana semua agama di atas ada penganutnya. Hal tersebut menunjukkan bahwa penduduk Kalsel sudah semakin heterogen.

Oleh karena itu materi dakwah yang bermuatan kerukunan semakin penting disiarkan melalui radio. Tetapi jika melalui siaran dakwah frekuensi dan alokasi waktunya terlalu sedikit, maka materi kerukunan ini dapat pula disiarkan melalui acaraacara lain, seperti acara pendidikan dan kebudayaan. Melihat persentasi acara pendidikan dan kebudayaan pada 16 radio di atas, maka tampaknya persentasinya lebih besar. Oleh karena itu materi kerukunan beragama ini dapat juga disiarkan melalui acara-acara pendidikan dan kebudayaan.

\section{Simpulan}

Setelah mengikuti uraian di atas dapatlah disimpulkan bahwa ajaran Islam kaya sekali dengan materi ajaran tentang kerukunan beragama. Materi ini perlu sekali disosialisasikan ke tengah masyarakat, di antaranya melalui radio-radio, yang di Kalimantan Selatan ini cukup banyak. Rata-rata radio yang ada di daerah ini sudah memiliki siaran dakwah Islam, namun persentasi waktunya sangat sedikit dibanding dengan acara-acara lainnya, dan dari yang sedikit itu selama ini masih jarang sekali yang diisi dengan materi kerukunan beragama. 
Ke depan ada baiknya materi ajaran agama tentang kerukunan disiarkan juga melalui acara-acara pendidikan dan kebudayaan. Di sini tak saja ajaran agama, tetapi nilai-nilai budaya lokal yang berbuatan kerukunan pun bisa disiarkan. Apabila materi acara diolah dengan baik, tentu akan menarik, dan yang lebuih penting lagi berguna bagi masyarakat untuk meningkatkan kerukunan serta terhindar dari perpecahan dan konflik bernuansa SARA.

\section{Daftar Pustaka}

Departemen Agama RI, Alquran dan Terjemahnya, (Jakarta: Proyek Pengadaan Kitab Suci Alquran, 1984/1985).

Departemen Agama RI, Konflik Sosial Bernuansa Agama, (Jakarta; Proyek Peningkatan Pengkajian Kerukunan Hidup Umat Beragama, 2003).

Departemen Agama Kantor Wilayah Kementerian Agama Kalsel, Profil Kerukunan, (Banjarmasin:Sub Bagiam Humas dan KUB, 2006).

Depatemen Pendidikan dan Kebudayaan RI, Kamus Besar Bahasa Indonesia, (Jakarta: Balai Pustaka, 1990).

Effendi, Onong Uchjana, Ilmu, Teori dan Filsafat Komunikasi, (Bandung: Citra Aditya Bhakti, 1993).

Haekal, Muhammad Husain, Hayatu Muhammad, Alih bahasa Ali Audah, Sejarah Hidup Muhammad, (Jakarta: Litera Antarnusa, 1990).

Hasan, Muhammad Tholhah, Islam Dalam Perspektif Sosio-Kultural, Jakarta: lantabora Press, 2005).

Himpunan Fatwa Majelis Ulama Indonesia, (Jakarta: Departemen Agama dan MUI, 2003).

Imam al-Bukhari, Shahih al-Bukhari, Jilid IV, JUZ 8, (Beirut: Dar al-Fikr, 1401 H).

Imam AR, Obyek Wisata Nusantara, (Jakarta: Fery Agung, 2008).

Imam Ibnu Katsir, Tafsir Ibnu Katsir, Jilid V, Alih bahasa Salim Bahreisy dan Said Bahreisy, (Surabaya: Bina Ilmu, 1999).

Komisi Penyiaran Indonesia Daerah (KPID) Kalimantan Selatan, Berkas Evaluasi Dengar Pendapat (EDP) Radio-radio Siaran Swasta Niaga di Kalimantan Selatan, untuk permohonan Perpanjangan Izin Penyelenggaraan Penyiaran, (Banjarmasin: KPID Kalsel, Maret 2016).

Kusnawan, Aep, "Tabligh Melalui Radio", dalam Aep Kusnawan, et al., (1995), Komunikasi Penyiaran Islam, (Bandung: Fakultas Dakwah IAIN Sunan Gunung Jati, 1995).

Kuswandi, Wawan, Komunikasi Massa: Sebuah Analisis Media Radio, (Jakarta: Rineka Cipta, 1996).

Lubis, M. Ridwan (Editor), Menelusuri Kearifan Lokal di Bumi Nusantara, (Jakarta: Puslitbang Kehidupan Beragama Departemen Agama RI, 2005).

Makkie, Ahmad dan Sjamsiar Seman, Peribahasa dan Ungkapan Tradisional Bahasa Banjar, (Banjarmasin: Dewan Kesenian Daerah Kalimantan Selatan, 1996).

Mufid, Ahmad Syafii,"Paham Islam Transnasional dan Demokratisasi di Indonesia, dalam Ahmad Syafii Mufid (Editor), Perkembangan Paham Keagamaan Transnasional di Indonesia, (Jakarta: Kementerian Agama RI, 2011)

Perlukah UU Kerukunan Umat Beragama?", Tempo, Edisi Januari 2001.

Potret Kerukunan Beragama Mancanegara", Tempo, Edisi Januari 2001.

Qardhawi, Yusuf, Fatawa Qardhawi, Alih bahasa Abdurrahman Ali Bauzir, (Jakarta: Risalah Gusti, 1994). 
Rais, Amien: "Ketimpangan Sosial Pemicu Konflik”, Gatra, 15 Juni 2002.

Sudjangi, "Konflik-konflik Sosial Bernuansa Agama (Studi Kasus Kerusuhan Ambon, dalam Departemen Agama RI, Konflik Sosial Bernuansa Agama, (Jakarta; Proyek Peningkatan Pengkajian Kerukunan Hidup Umat Beragama, 2003).

Yunus, Mahmud, Kamus Arab-Indonesia, (Jakarta: Yayasan Penyelenggara Penterjemah dan Pentafsir Alquran, 1973). 